\title{
Mengembangkan Kemampuan Penalaran Statistik dan Berpikir Kreatif Matematis Mahasiswa Melalui Pendekatan Open-ended
}

\author{
Ratna Sariningsih $^{1}$ *, Indri Herdiman ${ }^{1}$ \\ ${ }^{1}$ Jurusan Pendidikan Matematika, IKIP Siliwangi Bandung. Jalan Sudirman No.3, \\ Kota Cimahi 40526, Indonesia. \\ * Corresponding Author. Email: ratnasariningsih345@gmail.com \\ Received: 30 October 2017; Revised: 20 Desember 2017; Accepted: 28 December 2017
}

\begin{abstract}
Abstrak
Penelitian ini bertujuan untuk menelaah peranan pembelajaran open-ended dan tingkat kemampuan awal statistik matematis mahasiswa terhadap kemampuan penalaran statistik dan berpikir kreatif matematis ditinjau secara keseluruhan dan pada tingkat kemampuan awal statistik matematik mahasiswa (Tinggi, Sedang, Rendah) di Kota Cimahi. Penelitian ini merupakan penelitian eksperimen dengan desain kelompok kontrol dan post-test. Populasi dalam penelitian ini adalah seluruh mahasiswa jurusan matematika di Kota Cimahi, sampelnya adalah dua kelas mahasiswa semester dua dari salah satu perguruan tinggi di Kota Cimahi yang dipilih secara acak dari kelas yang ada. Instrumen yang digunakan adalah tes kemampuan penalaran statistik dan berpikir kreatif matematis mahasiswa. Hasil tes kemudian dianalisis menggunakan uji $\mathrm{t}$ dan ANOVA. Hasil penelitian menunjukkan bahwa (1) Kemampuan penalaran statistik matematis mahasiswa yang memperoleh pendekatan pembelajaran open-ended lebih baik dibandingkan pembelajaran konvensional; (2) terdapat perbedaan yang signifikan kemampuan penalaran statistik matematis mahasiswa pada kategori TKASM baik, sedang dan kurang, pada taraf signifikansi 5\%; (3) kemampuan berpikir kreatif matematis mahasiswa yang memperoleh pendekatan pembelajaran open-ended lebih baik dibandingkan pembelajaran konvensional. (4) Terdapat perbedaan yang signifikan antara kemampuan berpikir kreatif matematis mahasiswa pada TKASM Tinggi terhadap TKASM Sedang pada taraf signifikansi $5 \%$.
\end{abstract}

Kata Kunci: pendekatan open-ended, penalaran statistik matematis, berpikir kreatif matematis.

\section{Developing Students'Mathematical Creative Thinking and Statistical reasoning through Open-ended Approach in Cimahi City}

\begin{abstract}
This research aimed to know how open-ended approach and TKASM give the influence to reasoning of statistics mathematics and creative mathematical thinking ability in Cimahi. It was a quasi-experimental research using the pretest-posttest non-equivalent group design. The research population comprised all year undergraduate students in Cimahi. From the population, two classes were randomly selected as the sample of research.instrument of tgis research were the test of statistic reasoning ability and the test of creative thinking ability. The result of the tes was analized by t-test and ANOVA. The result showed that (1) reasoning of statistic mathematics ability of undergraduate students which is used open-ended approach was better than conventional learning; (2) there was a significant difference of reasoning of statistics mathematics ability of undergraduate students in the three categories of TKASM (good, medium and low) at significance level of 5\%. (3) The ability of mathematical creative thinking of undergraduate students with open-ended learning approach was better than conventional learning. (4) There was a significant difference between undergraduate students' mathematical creative thinking ability in high level of TKASM with medium level of TKASM at the level of significance of $5 \%$.
\end{abstract}

Keywords: open-ended approach, mathematical statisticreasoning, mathematical creative thinking.

How to Cite: Sariningsih, R., \& Herdiman, I. (2017). Mengembangkan kemampuan penalaran statistik dan berpikir kreatif matematis mahasiswa di Kota Cimahi melalui pendekatan open-ended. Jurnal Riset Pendidikan Matematika, 4(2), 239-246. doi:http://dx.doi.org/10.21831/jrpm.v4i2.16685

Permalink/DOI: http://dx.doi.org/10.21831/jrpm.v4i2.16685 


\title{
Jurnal Riset Pendidikan Matematika, 4 (2), 2017 - 240
}

\author{
Ratna Sariningsih, Indri Herdiman
}

\section{PENDAHULUAN}

Kurikulum di perguruan tinggi adalah suatu program yang dirancang dengan tujuan untuk menghasilkan lulusan yang memiliki kualitas setara dengan kualifikasi yang disepakati dalam Kerangka Kualifikasi Nasional (KKNI). Strategi pengembangan kurikulum bertujuan untuk mewujudkan proses pembelajaran aktif, sehingga menjadi pembelajaran yang dapat memfasilitasi mahasiswa untuk membangun pengetahuan serta menjadi mahasiswa yang berprestasi serta menguasai berbagai bidang pengetahuan. Tak hanya itu, diharapkan mahasiswa dapat mengaplikasikan kemampuan dan ilmu pengetahuan yang mereka miliki dalam kehidupan, demikian halnya dengan ilmu tentang statistika.

Statistika memegang peranan penting dalam pendidikan terutama dalam kehidupan manusia. Dari mulai aktivitas di laboratorium, riset di pasar hingga berbagai aktivitas dalam pengelolaan pemerintahan. Oleh karena itu, pemahaman dasar calon sarjana terhadap statistika menjadi sangat penting dan sangat mendasar. Hal ini sejalan dengan pendapat Mavrotheris (Zuhri, 2015) yang menyatakan bahwa "Statistics education is becoming the focus of reformers in mathematics education as a vital aspect of the education of citizens in democratic societies". Terlihat bahwa statistika menjadi fokus dalam reformasi pendidikan matematika.

Statistika merupakan salah satu mata kuliah yang harus diberikan kepada mahasiswa, terutama Jurusan Pendidikan Matematika. Salah satu tujuan pembelajaran statistika adalah untuk mengembangkan kemampuan penalaran statistik. Kemampuan ini terkait dengan kemampuan seseorang dalam memahami konsep-konsep dasar dan logika penalaran statistik, serta kemampuan praktis dalam memilih, menghasilkan, dan menafsirkan metode deskriptif dan inferensial dengan cara yang tepat (Garfield dalam Nurhairiyah \& Manfaat, 2013). Materi statistika yang diajarkan disusun dengan tujuan membantu mahasiwa dalam memahami dan menangani ketidakpastian, variabilitas dari informasi statistik yang diperoleh. Selain itu, diharapkan mahasiswa dapat menguasai berbagai aplikasi statistik dan dapat menerapkannya dalam kehidupan sehari-hari atau bidang studi lain.

Penalaran statistik adalah sebuah bentuk penalaran terkait dengan angka-angka yang bersifat probabilitas. Penalaran statistik dapat dimanfaatkan dalam proses penarikan kesimpulan serta pembuatan keputusan dalam keadaan yang tidak dapat diekspresikan dari sudut pandang probabilitas peluang yang dikenal dan diakui. Untuk mengetahui kemampuan penalaran seseorang, dapat dilakukan tes kemampuan penalaran statistik. Tes ini bertujuan untuk mengukur kemampuan penalaran statistik, yang berlandaskan "mengapa (why) dan bagaimana (how)". Terkait dengan hal tersebut, tes kemampuan penalaran statistik lebih tepat dibuat dalam bentuk essai. Akan tetapi, bentuk tes essai memiliki beberapa kelemahan diantaranya terdapat kecenderungan tester yang lebih banyak bersifat subjektif, kurang dapat menampung atau mencakup luasnya materi yang diberikan kepada, dan membutuhkan waktu yang lama dalam melakukan pengkoreksian jawaban (Sudijono, 2008, p.103).

Selain penalaran statistik, pengembangan kemampuan berpikir kreatif sangat penting bagi setiap mahasiswa atau calon guru. Hal ini dikarenakan hampir dalam semua disiplin ilmu atau dunia kerja mensyaratkan seseorang untuk mampu menganalisis dan mensitesis berbagai konsep serta harus mampu melihat keterkaitan antarkonsep-konsep untuk digunakan dalam upaya menyelesikan suatu masalah. Pada dasarnya, setiap orang memiliki potensi kreatif, namun kemampuan berpikir kreatif tidak tumbuh di ruang hampa, melainkan memerlukan daya dukung. Menurut Isaken (Alexander, 2007) daya dukung berpikir kreatif dapat berupa konteks, situasi atau faktor sosial. Proses berpikir itu ditentukan oleh situasi dan kondisi sosial pada saat itu.

Berpikir kreatif memuat aspek keterampilan kognitif, afektif, dan metakognitif. Keterampilan kognitif tersebut berkaitan dengan kemampuan mengidentifikasi masalah dan peluang, menyusun pertanyaan yang baik dan berbeda, mengidentifikasi data yang relevan dan yang tidak relevan, masalah dan peluang yang produktif. Selain itu, kemampuan ini terkait juga dengan kemampuan dalam menghasilkan banyak ide (fluency), menghasilkan ide yang berbeda (flexibility), serta produk atau ide yang baru (originality), memeriksa dan menilai hubungan antara pilihan dan alternatif, mengubah pola pikir dan kebiasaan lama, menyusun hubungan baru, memperluas dan memperbaharui rencana atau ide.

Sumarno (2010) mengemukakan bahwa berpikir kreatif memuat komponen keaslian (originality), pandangan yang tajam (sharp 


\section{Jurnal Riset Pendidikan Matematika, 4 (2), 2017 - 241}

Ratna Sariningsih, Indri Herdiman

insight), dan proses generatif. Beberapa langkah dalam berfikir kreatif adalah: mengajukan pertanyaan, mentransformasi informasi ke dalam pandangan baru dan open minded, mencari hubungan antar sesuatu yang berbeda, melihat antara yang satu dengan yang lainnya, menghasilkan sesuatu yang baru dan berbeda, serta mempertimbangkan intuisi.

Kemampuan penalaran statistik dan berpikir kreatif matematis mahasiswa sangat penting untuk dimiliki dan dikembangkan. Sayangnya, fakta di lapangan menunjukkan bahwa kemampuan penalaran statistik dan berpikir kreatif matematis mahasiswa masih kurang. Hal ini dapat dilihat dari hasil studi pendahuluan yang dilakukan selama beberapa semester terhadap mahasiswa Jurusan Pendidikan Matematika yang dilakukan oleh peneliti. Lemahnya kemampuan reflektif matematis mahasiswa khususnya di Jurusan Pendidikan Matematika STKIP Siliwangi, menunjukkan bahwa umumnya kemampuan berpikir reflektif dan pembuktian matematik mahasiswa masih berada dalam kategori rendah. Hal ini terlihat dari 40 mahasiswa, 30 mahasiswa masih mengalami kesulitan dalam menyelesaikan soal pembuktian yang harus disertai alasan dan soal-soal yang tidak sederhana (melibatkan berbagai konsep). Hanya 10 mahasiswa yang dapat menyelesaikan soalsoal tersebut. Dengan kata lain, hanya 25\% mahasiswa yang mampu menyelesaikan soal tersebut. Hal tersebut menjadi salah stau bukti bahwa kemampuan berpikir reflektif matematis mahasiswa masih rendah.

Bertolak dari pemikiran tersebut, untuk mewujudkan standar kompetensi baik yang tercantum dalam kurkulum KKNI maupun yang dirumuskan dalam lampiran Peraturan Menteri Pendidikan Nasional No 23 tahun 2006, pengembangan model dan sistem asesmen pembelajaran Matematika-Sains terpadu berorientasi pemecahan masalah open-ended agumentatif merupakan alternatif pilihan yang tepat (Depdiknas, 2006). Secara teoretis pembelajaran yang berorientasi pada pemecahan masalah open-ended argumentatif akan memberikan kesempatan pada siswa maupun mahasiswa untuk membangun kemampuan berpikir penalaran statistik, berpikir kreatif dan berpikir reflektif melalui pengembangan berbagai alternatif solusi, dan mengemukakan argumentasi-argumenasi atas pilihannya.

Pendekatan open-ended menurut Becker dan Shigeru (Mahmudi, 2008), pada awalnya dikembangkan di Jepang pada tahun 1970-an, peneliti-peneliti Jepang melakukan proyek penelitian pengembangan metode evaluasi keterampilan berpikir tingkat tinggi dalam pendidikan matematika dengan menggunakan soal atau masalah terbuka (open-ended problem) sebagai tema dalam pembelajaran. Meskipun pada mulanya pengembangan soal terbuka dimaksudkan untuk mengevaluasi keterampilan berpikir tingkat tinggi, selanjutnya disadari bahwa pembelajaran matematika yang menggunakan soal terbuka mempunyai potensi yang kaya untuk meningkatkan kualitas pembelajaran.

Menurut Mahmudi (2008), soal terbuka (open-ended problem) adalah soal yang mempunyai banyak solusi atau strategi penyelesaian. Hal ini sesuai dengan pendapat Suherman, et. al (Herdiman, 2015, p.18) yang berpendapat bahwa problem yang diformulasikan memiliki multijawaban yang benar disebut problem tak lengkap atau disebut juga problem open-ended atau problem terbuka. Penerapan problem openended dalam kegiatan pembelajaran adalah ketika siswa diminta mengembangkan metode, cara, atau pendekatan yang berbeda dalam menjawab permasalahan yang diberikan dan bukan berorientasi pada jawaban atau hasil akhir. Tujuan utama siswa dihadapkan dengan problem open-ended adalah bukan untuk mendapatkan jawaban tetapi lebih menekankan pada bagaimana cara siswa/mahasiswa sampai pada suatu jawaban. Jadi, tidak hanya ada satu pendekatan atau metode dalam memperoleh jawaban, namun beberapa atau banyak.

Dalam membuat masalah open-ended, Jerry P. Becker \& Shigeru Shimada (Herdiman, 2015, p.20) memberikan beberapa hal yang dapat dijadikan acuan dalam mengkreasi masalah tersebut, antara lain (1) menyajikan permasalahan melalui situasi fisik yang nyata dimana konsep matematika dapat dikaji dan diamati siswa; (2) soal-soal pembuktian dapat diubah sedemikian rupa sehingga siswa dapat menemukan hubungan dan sifat-sifat dari variable dalam masalah itu; (3) menyajikan bangun-bangun geometri sehingga siswa dapat membuat suatu konjektur; (4) memberikan suatu barisan bilangan atau tabel bilangan sehingga siswa dapat menemukan aturan matematika; serta (5) memberikan contoh konkret dalam beberapa kategori sehingga siswa dapat mengelaborasi sifat-sifat dari contoh itu untuk menemukan sifat-sifat yang umum.

Sejalan dengan uraian sebelumnya, dirasa penting bagi peneliti untuk melakukan penelitian yang berjudul "Mengembangkan kemampuan 


\section{Jurnal Riset Pendidikan Matematika, 4 (2), 2017 - 242}

Ratna Sariningsih, Indri Herdiman

penalaran matematis, berpikir kreatif dan reflektif matematis serta kemandirian belajar mahasiswa di kota Cimahi melalui pendekatan Openended". Adapun tujuan penelitian ini adalah untuk menelaah secara mendalam peranan pembelajaran open-ended dan tingkat kemampuan awal statistik matematis mahasiswa terhadap pencapaian kemampuan penalaran statistik dan kemampuan berpikir kreatif ditinjau secara keseluruhan dan pada tingkat kemampuan awal matematika siswa (Tinggi, Sedang, Rendah). Selain itu, terkait hasil-hasil temuan dalam penelitian, selanjutnya dicari upaya mengatasi kesulitan/kendala yang ditemui dalam upaya meningkatkan kemampuan penalaran statistik dan kemampuan berpikir kreatif matematis mahasiswa.

\section{METODE}

Penelitian ini adalah bentuk penelitian eksperimen, dengan disain kelompok kontrol dan post-test. Penelitian ini diharapkan dapat meningkatkan kemampuan penalaran statistik matematis dan berpikir kreatif dan reflektif, serta kemandirian belajar mahasiswa. Populasi dalam penelitian ini adalah seluruh mahasiswa perguruan tinggi di Kota Cimahi, sedangkan sampelnya adalah mahasiswa semester 2 dari salah satu mahasiswa perguruan tinggi yang ditetapkan secara purposif di Kota Cimahi, dan dipilih dua kelas secara acak dari mahasiswa tingkat 2 yang ada. Kemudian dari kedua kelas tersebut ditetapkan secara acak yang menjadi kelas eksperimen dan kelas kontrol. Tes kemampuan penalaran statistik matematik dan kemampuan berpikir tingkat tinggi matematis mahasiswa masing-masing disusun mengacu pada karakteristik kemampuan berpikir tingkat tinggi matematis serta pedoman penyusunan tes yang baik. Data akan dianalisis dengan menggunakan uji statistik t, uji ANOVA dan uji dengan statistik $x^{2}$ (untuk uji asosiasi antar variabel). Adapun desain penelitiannya adalah sebagai berikut.
$\begin{array}{llll}\mathrm{A} & \mathrm{O} & \mathrm{X} & \mathrm{O}\end{array}$
A $\mathrm{O} \quad \mathrm{O}$

(Ruseffendi, 2005, p.50)

Keterangan:

A: Pengambilan sampel secara acak kelas

$\mathrm{O}$ : Pretes $=$ post-test (tes kemampuan penalaran statistik, berpikir kreatif dan reflektif matematis).

$\mathrm{X}$ : Perlakuan pembelajaran dengan pendekatan open Ende

Sebelum perlakuan dilakukan, masiswa akan diberikan tes kemampuan awal statistik matematis yang nantinya mahasiswa tersebut akan diklasifikasikan ke dalam Tingkat Kemampuan Awal Statistik Matematis Mahasiswa (TKASM). Setelah mengetahui TKASM, eksperimen mulai dilakukan dengan setting memberikan perlakuan pembelajaran kepada mahasiswa dengan pembelajaran open-ended (kelas eksperimen) dan pembelajaran konvensional (kelas kontrol) yang diakhir perlakuan akan dilakukan tes akhir (post-test) tahap pertama untuk melihat bagaimana perkembangan kemampuan berpikir tingkat tinggi matematis mahasiswa.

Dalam menyusun soal tes, terlebih dahulu dibuat kisi-kisi soal kemudian dilanjutkan dengan menyusun soal beserta alternatif jawaban dari masing-masing butir soal. Selanjutnya, supaya memiliki validitas isi, soal-soal tersebut dikonsultasikan terlebih dahulu dengan dosen ahli. Untuk validitas muka soal disesuaikan dengan silabus dan dikonsultasikan dengan dosen pembina mata kuliah statistik dasar di kampus tersebut. Setelah itu, agar memiliki validitas empiris soal-soal tersebut diujicobakan kemudian dihitung validitas, reliabilitas, daya pembeda, dan indeks kesukarannya.

Pengelompokkan kemampuan awal mahasiswa dikelompokkan dalam kelompok tinggi, sedang, dan rendah, baik pada kelas eksperimen maupun kelas kontrol. Pengelompokan mahasiswa didasarkan pada hasil tes kemampuan awal yang diberikan kepada mahasiswa sebelum perlakuan pembelajaran (eksperimen) dilakukan, yang dikategorikan.

Tabel 1. Kategori Pengelompokan Tingkat Kemampuan Awal Siswa

\begin{tabular}{cc}
\hline Interval & Kategori \\
\hline$x>(\bar{x}>0,5 S D)$ & Tinggi \\
$(\bar{x}-0,5 S D) \leq x \leq(\bar{x}>0,5 S D)$ & Sedang \\
$(\bar{x}-0,5 S D)<x$ & Rendah \\
\hline
\end{tabular}

\section{HASIL DAN PEMBAHASAN}

Analisis hasil penelitian ini diuraikan untuk beberapa tujuan, yaitu: menjawab permasalahan yang telah dirumuskan, mengetahui ketercapaian tujuan penelitian, dan menguji kebenaran hipotesis berdasarkan data dari setiap variabel yang telah dikumpulkan. Analisis data hasil penelitian difokuskan untuk menjelaskan secara komprehensif tentang: kemampuan awal matematis (TKASM) mahasiswa sebagai kemampuan prasyarat sebelum pembelajaran; pencapaian kemampuan penalaran statistis matematis (KPSM), pencapaian kemampuan berpikir 


\section{Jurnal Riset Pendidikan Matematika, 4 (2), 2017 - 243}

Ratna Sariningsih, Indri Herdiman

kreatif Matematis (KBKM) serta asosiasi antara kemampuan penalaran statistik matematis dan berpikir kreatif mataematis.

Pemberian tes kemampuan awal statistis Matematis (KASM) kepada mahasiswa sebagai sampel penelitian ini dimaksudkan untuk: (1) mengetahui kemampuan prasyarat mahasiswa pada materi statistika deskriptif. Setelah dilakukan uji normalitas sebaran data kemampuan penalaran matematis dan kemampuan berpikir kreatif matematis mahasiswa, secara keseluruhan diperoleh hasil bahwa data tidak berdistribusi normal. Untuk kemampuan berpikir reflektif matematis serta kemandirian belajar mahasiswa, secara keseluruhan diperoleh bahwa data yang diperoleh berdistribusi normal. Berdasarkan temuan tersebut, maka pengujian perbedaan rerata kemampuan dan disposisi tersebut dilakukan dengan uji perbedaan dua rerata dengan uji $t$ (KPSM dan KBKM) dan uji Mann Whitney untuk KBRM serta kemandirian belajar mahasiswa. Rekapitulasi hasil uji tersebut tersaji pada Tabel 2.

Tabel 2. Rekapitulasi Hasil Uji Perbedaan Rerata dan Uji Mann Whitney

\begin{tabular}{|c|c|c|}
\hline $\begin{array}{l}\text { Kemampuan } \\
\text { dan Disposisi }\end{array}$ & Sig. & Interpretasi \\
\hline $\begin{array}{c}\text { Kemampuan } \\
\text { Penalaran } \\
\text { Matematis }\end{array}$ & 0,003 & $\begin{array}{l}\text { Kemampuan penalaran sta- } \\
\text { tistik matematis mahasiswa } \\
\text { yang pembelajarannya } \\
\text { menggunakan pendekatan } \\
\text { open-ended lebih baik } \\
\text { dibandingkan pembelajaran } \\
\text { konvensional pada taraf } \\
\text { signifikansi 5\% }\end{array}$ \\
\hline $\begin{array}{l}\text { Kemampuan } \\
\text { Berpikir } \\
\text { Kreatif } \\
\text { Matematis }\end{array}$ & 0,000 & $\begin{array}{l}\text { Kemampuan berpikir kreatif } \\
\text { matematis mahasiswa yang } \\
\text { pembelajarannya mengguna- } \\
\text { kan pendekatan open-ended } \\
\text { lebih baik dibandingkan } \\
\text { pembelajaran konvensional } \\
\text { pada taraf signifikansi } 5 \%\end{array}$ \\
\hline
\end{tabular}

Berdasarkan Tabel 2, diperoleh interpretasi sebagai berikut: Pertama, kemampuan Penalaran Statistik matematis mahasiswa yang pembelajarannya menggunakan Pendekatan open-ended lebih baik dibandingkan pembelajaran konvensional secara keseluruhan. Kemampuan penalaran statistik matematis pada kelas open-ended $(11,363)$ dan kelas konvensional $(10,06)$ termasuk dalam kategori Cukup dari skor ideal 16.

Kedua, kemampuan Berpikir Kreatif Matematis mahasiswa yang pembelajarannya menggunakan Pendekatan open-ended lebih baik dibandingkan pembelajaran konvensional secara keseluruhan. Kemampuan berpikir kreatif matematis siswa pada kelas dengan pendekatan open-ended $(12,74)$ dan kelas konvensional $(8,66)$ tergolong dalam kategori Cukup dari skor ideal 16.

Adapun rangkuman uji anova dua jalur untuk kemampuan penalaran statistik matematis mahasiswa jika ditinjau berdasarkan faktor pendekatan pembelajaran dan TKASM disajikan dalam Tabel 3.

Tabel 3. Rangkuman Uji Anova Dua Jalur Kemampuan Penalaran Statistik Matematis Mahasiswa

\begin{tabular}{cccccc}
\hline Source & $\begin{array}{c}\text { Type III } \\
\text { Sum of }\end{array}$ & df & $\begin{array}{c}\text { Mean } \\
\text { Square }\end{array}$ & F & Sig \\
\hline Corrected & $196,658 \mathrm{a}$ & 5 & 9,332 & 11,761 & 000 \\
Model & $8,112,85$ & 1 & $, 112,895$ & $2,425,97$ & 000 \\
Error & & & & & \\
Total & 29,304 & 1 & 9,304 & 8,763 & 004 \\
Corrected & 127,928 & 2 & 3,964 & 19,127 & 000 \\
Total & 25,478 & 2 & 2,743 & 3,811 & 026 \\
\hline
\end{tabular}

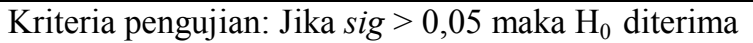

Tabel 3 menunjukkan bahwa kemampuan penalaran statistik matematis mahasiswa memperoleh nilai $\operatorname{sig}=0,004$; atau dengan kata lain nilai sig $<0,05$. Berdasarkan hal tersebut dapat disimpulkan bahwa terdapat perbedaan yang signifikan antara kemampuan statistik matematis mahasiswa yang pembelajarannya menggunakan pendekatan open-ended dengan yang pembelajarannya menggunakan pembelajaran konvensional pada taraf signifikansi 5\%. Implikasinya adalah pembelajaran matematika yang menggunakan pendekatan open-ended dapat membantu mengembangkan hasil belajar matematika mahasiswa. Berikutnya akan dilihat pengaruh Tingkat Kemampuan Awal Siswa (TKASM) terhadap Hasil Belajar Matematika mahasiswa.

Dari Tabel 3, untuk kemampuan penalaran matematis mahasiswa, diperoleh nilai $\operatorname{sig}=0,000$; atau dengan kata lain nilai sig $<0,05$; berdasarkan hal tersebut dapat disimpulkan bahwa paling tidak terdapat satu kelompok mahasiswa dengan TKASM tertentu yang kemampuan berpikir tingkat tinggi matematis mahasiswanya berbeda secara signifikan dengan TKASM lainnya pada taraf signifikansi 5\%. Untuk mengetahui TKASM mana yang berbeda secara signifikan dilakukan uji scheffe. Hasil perhitungannya disajikan pada Tabel 4.

Berdasarkan Tabel 4, dapat disimpulkan bahwa terdapat perbedaan yang signifikan pada kemampuan penalaran statistik matematis mahasiswa berada dalam ketiga kategori TKASM 
(baik, sedang dan kurang) pada taraf signifikansi 5\%. Implikasinya adalah kemampuan penalaran statistik matematis mahasiswa pada ketiga kategori TKASM (baik, sedang dan kurang) sama-sama berkembang dengan baik. Namun yang lebih berkembang adalah TKASM dengan kategori Baik.

Tabel 4. Uji Scheffe Kemampuan Penalaran Statistik

\begin{tabular}{ccc}
\hline TKASM (I) & TKASM (J) & Sig. \\
\hline Baik & Sedang & 0,000 \\
Sedang & Kurang & 0,185 \\
Baik & Kurang & 0,000 \\
\hline & (Diambil dari output SPSS.21)
\end{tabular}

Secara keseluruhan, hasil analisis data yang telah dilakukan menunjukkan bahwa pencapaian KPSM mahasiswa yang memperoleh pembelajaran open-ended secara signifikan lebih tinggi daripada pencapaian KPSM mahasiswa yang memperoleh pembelajaran konvensional pada setiap level kelas dan keseluruhan. Hal ini didasari oleh hasil uji statistik bahwa terdapat perbedaan rata-rata pencapaian KPSM mahasiswa antara yang memperoleh Pembelajaran open-ended dan pembelajaran konvensional. Perbedaan rata-rata pencapaian KPSM mahasiswa pada setiap level kelas dan keseluruhan memberikan gambaran bahwa kontribusi Pembelajaran open-ended lebih baik dibandingkan Pembelajaran konvensional dalam menghasilkan kemampuan penalaran statistik mahasiswa. Secara keseluruhan, kemampuan penalaran statistik matematis mahasiswa yang memperoleh Pembelajaran open-ended dan pembelajaran konvensional dalam kategori kurang. Meskipun demikian, dapat dikatakan bahwa pembelajaran open-ended dapat digunakan untuk meningkatkan kemampuan penalaran statistik mahasiswa.

Hasil penelitian ini relevan dengan temuan Dasari (2009) bahwa kemampuan penalaran statistik mahasiswa yang memperoleh pembelajaran model PACE lebih baik daripada pembelajaran konvensional. Rata-rata kemampuan penalaran statistik mahasiswa yang memperoleh pembelajaran model PACE lebih besar daripada rata-rata penalaran statistik mahasiswa yang memperoleh pembelajaran konvensional.

Selanjutnya, rangkuman uji anova dua jalur kemampuan berpikir kreatif matematis mahasiswa berdasarkan faktor pendekatan pembelajaran dan TKASM disajikan dalam Tabel 5 .

Berdasarkan Tabel 5 diketahui bahwa nilai $\operatorname{sig}=0,000$; atau dengan kata lain untuk kemampuan berpikir kreatif matematis mahasiswa memperoleh nilai sig $<0,05$. Dapat disimpulkan bahwa terdapat perbedaan yang signifikan antara retensi kemampuan berpikir kreatif matematis mahasiswa yang pembelajarannya menggunakan pendekatan open-ended dengan pembelajaran konvensional pada taraf signifikansi 5\%. Berdasarkan Tabel 5 diperoleh nilai $\operatorname{sig}=0,000$; atau dengan kata lain nilai sig < 0,05; hal tersebut dapat disimpulkan bahwa paling tidak terdapat satu kelompok siswa dengan TKASM tertentu yang retensi kemampuan berpikir tingkat tinggi matematis mahasiswanya berbeda secara signifikan dengan TKASM lainnya pada taraf signifikansi $5 \%$. Untuk mengetahui TKASM mana yang berbeda secara signifikan dilakukan uji scheffe.

Berdasarkan Uji Sceffe yang telah dilakukan dapat disimpulkan bahwa terdapat perbedaan yang signifikan antara kemampuan berpikir kreatif matematis mahasiswa pada TKASM Tinggi terhadap TKASM Sedang pada taraf signifikansi 5\% (terlihat dari sig. TKASM Tinggi terhadap TKASM Sedang ataupun sebaliknya $=0,001)$. Selain itu juga terdapat perbedaan yang signifikan antara kemampuan berpikir kreatif matematis mahasiswa pada TKASM Tinggi terhadap TKASM Kurang pada taraf signifikansi 5\% (terlihat dari sig. TKASM Tinggi terhadap TKASM Kurang ataupun sebaliknya $=0,001)$. Dalam hal ini kemampuan berpikir kreatif matematis mahasiswa TKASM Tinggi dan TKASM Kurang lebih baik dibandingkan mahasiswa dengan TKASM sedang. Implikasinya adalah kemampuan berpikir kreatif matematis mahasiswa pada TKASM Tinggi dan TKASM Kurang lebih berkembang dari TKASM Sedang.

Tabel 5. Rangkuman Uji Anova Dua Jalur Kemampuan Berpikir Kreatif Matematis Mahasiswa

\begin{tabular}{cccccc}
\hline Source & Type III Sum of Squares & Df & Mean Square & F & Sig. \\
\hline Corrected Model & $7,813,565$ & 1 & $7,813,565$ & $1,706,235$ & 000 \\
Intercept & 176,919 & 1 & 176,919 & 38,633 & 000 \\
Pembelajaran & 98,089 & 2 & 49,045 & 10,710 & 000 \\
TKASM_all & 11,678 & 2 & 5,839 & 1,275 & 285 \\
\hline
\end{tabular}

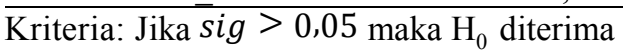




\section{Jurnal Riset Pendidikan Matematika, 4 (2), 2017 - 245}

Ratna Sariningsih, Indri Herdiman

Berdasarkan hasil dan temuan penelitian yang telah dilakukan, dapat diprediksi bahwa penerapan pembelajaran open-ended memiliki dampak atau berkontribusi terhadap terbentuknya kemampuan penalaran statistik mahasiswa, kemampuan berpikir kreatif matematis, dan kemampuan berpikir reflektif matematis mahasiswa. Dari hasil penelitian yang telah dilakukan, pembelajaran menggunakan pendekatan open-ended melalui kelompok kecil berjalan sesuai dengan yang diharapkan dan menunjukan peran yang berarti dalam meningkatkan kemampuan kemampuan penalaran statistik mahasiswa, kemampuan berpikir kreatif matematis, dan kemampuan berpikir reflektif matematis mahasiswa.

Materi yang disajikan dalam pembelajaran adalah tentang statistika dasar perguruan tinggi yaitu memahami pengertian statistika, macam-macam statistika sampai pengolahan data statistik. Salah satu contoh bentuk kegiatan dalam pembelajaran dengan pendekatan openended yang dapat meningkatkan beberapa kemampuan mahasiswa adalah pada tahap pertama, yaitu ketika siswa dihadapkan pada problem terbuka. Tahap ini menekankan pada bagaimana proses mahasiswa sampai pada sebuah solusi. Pada penelitian ini, peneliti menyajikan masalah sehari-hari yang berhubungan dengan materi agar siswa memperoleh pemahaman konsep. Dalam pembelajaran, peneliti menampilkan beberapa contoh gambar tentang materi statistika yang dikaitkan dengan kehidupan sehari-hari mereka. Pada pelaksanaan tahap ini di lapangan, peneliti memberikan pertanyaan kepada mahasiswa, apa yang dapat disimpulkan dari kegiatan mengamati. Selain pada tahap pertama, pada tahap kedua, juga terdapat aktivitas yang dapat menstimulasi kemampuankemampuan yang menjadi fokus peneliti. Pada tahap kedua, peneliti membimbing mahasiswa untuk menemukan pola dalam mengkontruksi permasalahannya sendiri. Dengan demikian, kemampuan-kemampuan tersebut akan dapat terstimulasi dan terasah dengan baik.

\section{SIMPULAN}

Penelitian ini memberikan beberapa simpulan antara lain: (1) kemampuan penalaran statistik matematis mahasiswa yang memperoleh pembelajaran dengan pendekatan open-ended lebih baik dibandingkan pembelajaran konvensional. (2) Terdapat perbedaan yang signifikan kemampuan penalaran statistik matematis mahasiswa pada ketiga kategori TKASM (baik, sedang dan kurang) pada taraf signifikansi 5\%. Implikasinya kemampuan penalaran statistik matematis mahasiswa pada ketiga kategori TKASM (baik, sedang dan kurang) sama-sama berkembang dengan baik. Namun yang lebih berkembang adalah TKASM dengan kategori Baik. (3) Kemampuan berpikir kreatif matematis mahasiswa yang memperoleh pembelajaran dengan pendekatan open-ended lebih baik dibandingkan pembelajaran konvensional. (4) Terdapat perbedaan yang signifikan antara kemampuan berpikir kreatif matematis mahasiswa pada TKASM Tinggi terhadap TKASM Sedang pada taraf signifikansi 5\%. Selain itu juga terdapat perbedaan yang signifikan antara kemampuan berpikir kreatif matematis mahasiswa pada TKASM Tinggi terhadap TKASM Kurang pada taraf signifikansi $5 \%$.

Terkait dengan hasil penelitian, perlu dilakukan pengembangan kemampuan penalaran statistik matematis mahasiswa. Hendaknya lebih diutamakan penggunaan konten-konten matematika yang esensial dan disertai dengan penyediaan bahan ajar dan bantuan dosen yang sesuai dengan kebutuhan mahasiswa.

\section{DAFTAR PUSTAKA}

Alexander, K. L. (2007). Effects instruction in creative problem solving on cognition, creativity, and satisfaction among ninth grade students in an introduction to world agricultural science and technology course. Disertasi pada texas tech university. Retrived from: http://oaktrust.library.tamu.edu/handle/1 969.1/5881.

Dasari, D. (2009). Meningkatkan kemampuan penalaran statisttis mahasiswa melalui pembelajaran model pace. Disertasi SPS.UPI, tidak diterbitkan.

Depdiknas. (2006). Permendiknas no.23 tahun 2006 standar kompetensi lulusan untuk satuan pendidikan dasar dan menengah. Jakarta; Depdiknas

Herdiman, I. (2015). Penerapan pendekatan open-ended untuk meningkatkan pemahaman dan penalaran matematik serta kemandirian belajar siswa SMP. Tesis STKIP Siliwangi, tidak diterbitkan.

Mahmudi, A. (2008). Mengembangkan soal terbuka (open-ended problem) dalam pembelajaran matematika. Retrived from: http://zonasabar.blogspot.com/2011/03/m 
Jurnal Riset Pendidikan Matematika, 4 (2), 2017 - 246

Ratna Sariningsih, Indri Herdiman

akalah-pembuatan-lks-lembar-kerja.html. [18 januari 2012].

Nurhairiyah \& Manfaat. (2013). Pengembangan instrumen tes untuk mengukur kemampuan penalaran statistikmahasiswa tadris matematika. Jurnal Eduma,2(2) .

Ruseffendi, E. T. (2005). Dasar-dasar penelitian pendidikan \& bidang non eksakta lainnya. Bandung: Tarsito

Sudijono, A. (2008). Pengantar evaluasi pendidikan. Jakarta: Raja Grafindo Persada
Sumarno, U. (2010). Berpikir dan disposisi matematik: apa, mengapa, dan bagaimana dikembangkan pada peserta didik. Bandung: FPMIPA UPI.

Zuhri, M. (2015). Karakteristik penalaran siswa kelas xi sekolah menengah atas tentang sampel yang memiliki kemampuan matematika rendah. Retrived from: https://wwwgoogle.co.id/?gws_rd=cr,ssl\& $\mathrm{ei}=1 \mathrm{pGV} 52 Z A c q J v Q S N 7$ paoCw $\mathrm{w} q=\mathrm{mav}$ rotheris+dalam+zuhri [24Mei 2016] 